\title{
Ecotourism development to preserve mangrove conservation effort: Case study in Margasari Village, District of East Lampung, Indonesia
}

\author{
WAWAN SETIAWAN, SUGENG P. HARIANTO, ROMMY QURNIATI" \\ Department of Forestry, Faculty of Agriculture, Universitas Lampung. J1 Soemantri Brojonegoro, Gedung Meneng, Bandar Lampung 35145, Lampung, \\ Indonesia. Tel.: +62-721-704946, Fax.: +62-721-770347. `email: rommy.qurniati@gmail.com
}

Manuscript received: 25 April 2017. Revision accepted: 7 June 2017.

\begin{abstract}
Setiawan W, Harianto SP, Rommy Qurniati R. 2017. Ecotourism development to preserve mangrove conservation effort: Case study in Margasari Village, District of East Lampung, Indonesia. Ocean Life 1: 14-19. The conservation efforts by Margasari community have produced the enhancement of mangrove forest areas, however the utilization of mangrove forest by people around was low. To make the conservation effort sustainable needs to develop mangrove ecotourism so they can utilize mangrove forest existence. This research intended to study the conservation and ecotourism effort in Margasari Village and the community perception of ecotourism development. This research was conducted in March-April 2017 in Margasari Village by interviewing 96 respondents. The data collection was undertaken through field observation, key informant interviews, and structured interviews with questionnaire. The result showed, the conservation effort was protecting, preserving, and utilizing of mangrove such as mangrove nursery, mangrove plantation, utilizing of jeruju and pedada fruit as food and counselling to the villagers not to cut mangrove and enter the mangrove forest. The ecotourism activities were boating around the mangrove, mangrove planting tourism, and bird watching. The conservation and ecotourism effort conduct by the people who joined community groups. But it was dominated by the group manager. So the financial benefit from ecotourism had limited for few people. Nevertheless, Margasari community agreed with the ecotourism development and was willing to participate in developing the ecotourism.
\end{abstract}

Keywords: Conservation effort, ecotourism, mangrove forest, community

\section{INTRODUCTION}

The existence of mangrove forest has an important role on the coastal area; mangrove vegetation has the ability to equalize the environment and neutralize the pollutant materials (Rochana 2011). Mangrove forests that have 200 $\mathrm{m}$ of mangrove thickness from the coastline with 30 trees/100 $\mathrm{m}$ of tree density and $15 \mathrm{~cm}$ of trunk diameter could muffle about $50 \%$ tsunami wave powers (Rusdianti 2012). Dense mangrove forests offer protection of coastal areas from tsunami waves. Mangrove protect coastline, enrich coastal waters, support coastal fisheries, yield beneficial forest products, serve as habitat for various kinds of fauna, and as sites for burgeoning ecotourism industry (Kusmana 2015). Sustainable management of mangrove forests will ensure these benefits for surrounding communities. The management challenge and forest protection in Indonesia often came from the local community around the forest. Magdalena (2013) reported that the protection by Sasak (Nusa Tenggara Barat) and Dayak Kenyah (Kalimantan Timur) communities have supported the sustainable forest management.

Most of the mangrove forest areas which grow along the coast are protected areas which inclined open for everyone who entered (open access) (Kustanti et al 2014). Lampung province had $1,105 \mathrm{~km}$ of the total coastline which was planted with mangroves as long as $896 \mathrm{~km}$ (Purnobaski 2001). Nowadays the mangrove forest ecosystem is threatened, and the extent of the damage to mangrove ecosystems is a cause for concern (Nugraha et al 2015). But mangrove forest area in Margasari has enhanced 117.59 ha during 2010-2013 (Cesario et al 2015). This expansion happened due to the emerging land and conservation effort through planting activity by community in Margasari and other parties outside the village (Monografi Desa Margasari 2012).

The utilization of mangrove forest by Margasari villagers is very limited. According to Ariftia et al. (2014), the direct utilization value of mangrove forest in Margasari is only $18 \%$ of the total economic value. The low use of mangroves could be a threat as Qurniati et al (2017a) revealed community surrounding the forest have limited capital, it could decrease the conservation effort by the community. The mangrove conservation effort should be equal to the sustainable utilization through developing mangrove-focused ecotourism. The ecotourism activities appreciated the local resource potential and based on community so it prevented the change of land ownership, social and cultural community because the community acted as subject and main beneficiaries, besides ecotourism also supported the effort of the sustainable economic development because of giving an alternative livelihood as income resources (Rizky et al. 2016). For a reason, this research intends to study the conservation and ecotourism effort by Margasari community and the social perception of ecotourism based on mangrove development. 


\section{MATERIALS AND METHODS}

\section{Study area}

The research was conducted in March and April 2017 in Margasari Village, Sub-district of Labuhan Maringgai, District of East Lampung, Lampung, Indonesia (Figure 1). This location was chosen because the surrounding community has an already established conservation effort which has resulted in the increase of mangrove forest area.

Data were collected using observation, structured and in-depth interview and literature study. The observation and in-depth interview were used to collect the data about the conservation efforts of the community. The structured interview used a questionnaire, to investigate community perception of ecotourism development. The literature study was used to collect data about the general description of Margasari Village and surrounding mangrove forest. There were six key individuals of samples in conservation effort who determined by using snowball sampling. Snowball sampling is a non-probability sampling technique in which a researcher begins with a small population of known individuals and expand the sample by asking those initial participants to identify others that should participate in the study. The respondents of ecotourism development were 90 respondents who measured by Slovin's formula. Slovin's Formula was used to determine the sample size of a population of 989 people for an interview by a questionnaire. The conservation effort was analyzed descriptively based on Indonesia Government Rule No 5 in 1990 and No 32 in 2004 regarding conservation effort. The questions of community perception of ecotourism development were categorized by scoring method to identify the level of community perception in ecotourism development based on mangrove.

\section{RESULTS AND DISCUSSION}

Based on the Indonesia Government Rule No 5 in 1990, conservation effort is managing and utilizing natural resources wisely to ensure the existence of it in this time and the future. This includes three key activities: protection, preservation and sustainable utilization of natural resources.

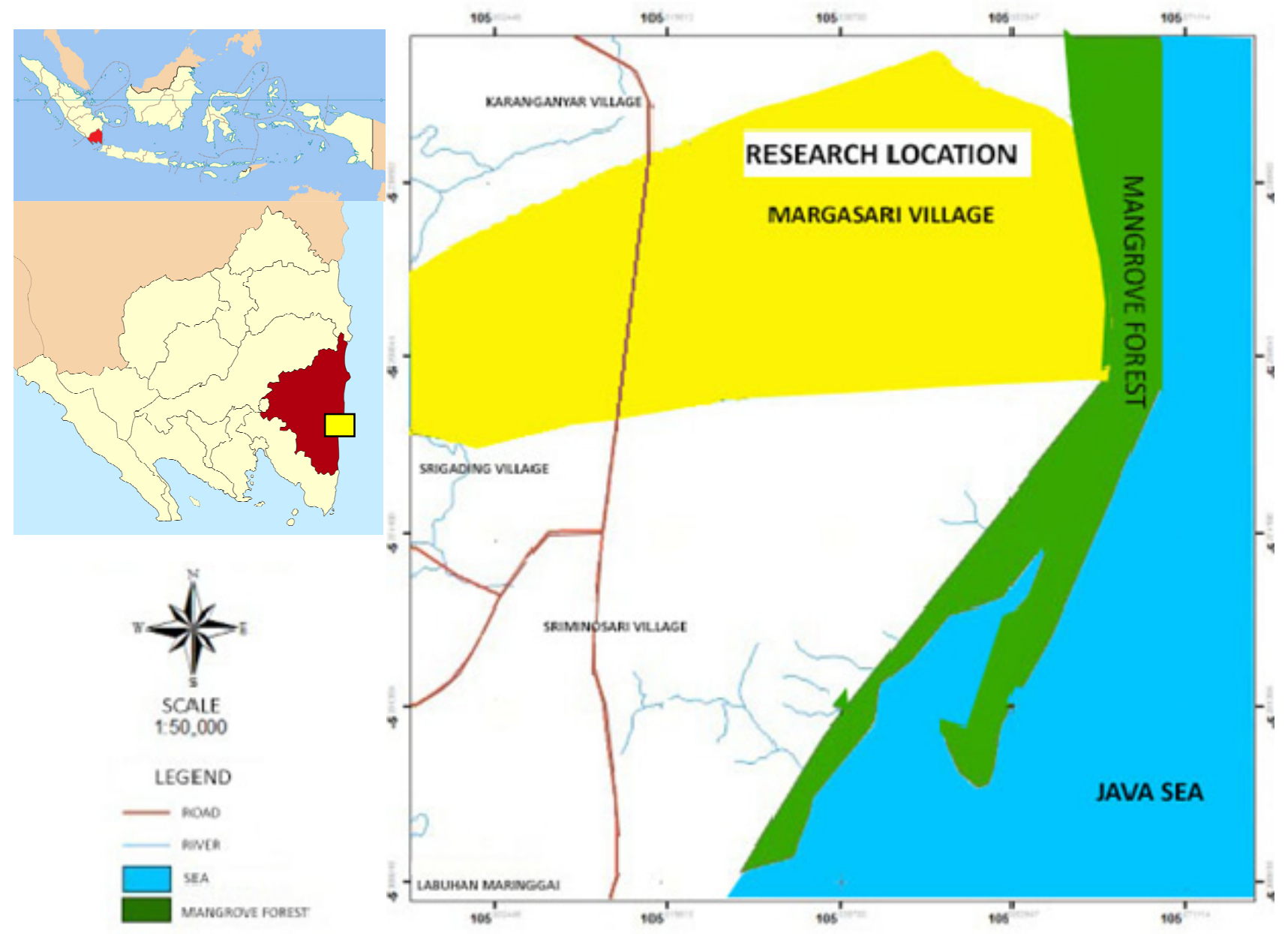

Figure 1. Map of study area showing mangrove forest and Margasari Village, Sub-district of Labuhan Maringgai, District of East Lampung, Lampung, Indonesia 


\section{Protection of mangrove forest}

Mangrove protection effort by Margasari community was to prohibit people to enter mangrove forest area and cut trees down. This conservation effort, as described in Laila (2014) is included in public environmentalist category, are the residents who attempt to improve the condition of the environment directly through their actions and behavior. In Margasari, the forest protection was conducted by Margajaya Group and Wanita Cinta Bahari (WCB) Group. The leader of Margajaya Group and all the group members appealed to the wider community through village events such as kumpulan kampung (village gathering), hajatan (party), or yasinan (prayers meeting). While the leader of WCB group gave a warning directly to the people who entered the mangrove forest and appealed to the community through pengajian (religious meeting) in order to not damage the mangrove. Reports were given directly to the village chief if there were people who damaged the mangrove forest. These protection activities were based on the responsibility to keep the mangrove forest sustainable. The others people in Margasari protect the mangrove forest by following the rules of mangrove so the mangrove could grow well without any disturbance from human.

\section{Preservation of mangrove forest resource}

The Margasari community preserves the mangrove forest by developing a nursery and planting mangroves. The nursery activities are conducted by Margajaya Group, which has ten members. The Margajaya Group took the seeds of mangrove fruit from inside mangrove forest area and planted them on the nursery site. The Margajaya Group sold the seeds for IDR $1.300 /$ seed (USD 0.1/seed). Unfortunately, the nursery project was suffering because the Margajaya Group was unable to compete with the group from Purworejo Village that had a seed certification. Purworejo village is approximately $20 \mathrm{~km}$ from Margasari Village and also have mangrove forest adjacent to Margasari mangrove forest.

The people who were not a member of any community groups participated in the mangrove planting in 2006-2007, and in December 2016 a government-initiated planting program took place. At present, the number of participatory community members has declined, only the members of Margajaya Group continue to plant the mangroves. Otherwise, Aflaha (2013) found that all people supported the mangrove planting activities as well as participated in the activity of sustaining the mangrove forest area.

The incentive factor for willingness to plant and develop mangrove nurseries in Margasari is economic. Community members received wages of IDR 50,000/day (USD 3.85). This wage was paid by the event organizer (outside parties), usually the local government (forestry service). But many mangrove programs from government were project oriented so the people who participated were low (Qurniati et al. 2017b).

\section{Utilization of mangrove forest}

The utilization of mangrove forest resources is limited to production of terasi (shrimp paste), jeruru (acanthus ilicifolius) leafs, pedada (sonneratia caseolaris) fruits and ecotourism activity. Terasi is paste for cook seasoning made from fermented baby shrimp. Terasi produces 2-3 times per week by Pengolah Terasi Groups. The average terasi production is $100 \mathrm{~kg} / \mathrm{month}$ with the price is IDR $30000 / \mathrm{kg}$ (USD $2.3 / \mathrm{kg}$ ). Terasi is sold to local markets and visitors in mangrove.

WCB Group produces chips from jeruru (acanthus ilicifolius) leafs and syrup from pedada (sonneratia caseolaris) fruits. This group utilized jeruju and pedada from mangrove forest area in Margasari. Initially, the syrup product was packaged in plastic bottles but glass bottles are now used to maintain the quality of syrup (Herwanti 2015). The productions of jeruju and pedada fruits were to order. In the local market, the consumers of these products are visitors. Whereas, Sabana (2014) said that mangrove syrup production had good prospects to be developed from the production and marketing sides.

Every month 2,200 kg of chips and 1,000 bottles of syrup are produced. This number was different in 2014, Ariftia et al. (2014) found the production number was $2,280 \mathrm{~kg}$ of chips and the syrup was 2,280 bottles monthly. This means the production has declined because of limited orders and the number of participant members who made it. The members had another activity like managing the household and helping their husband to manage ponds. According to their leader, the number of WCB Group members has decreased from 32 to 9 active members who managed pedada and jeruju fruits.

Besides terasi, jeruju and pedada products, Margasari community has been developing ecotourism since 2006 as one of economic utilization of the mangrove forest. Ecotourism activities include mangrove walking tracks, bird watching, reading house, boat trips through the mangroves, planting packages, and shrimp pond tours. The visitors were typical students, lecturers and researchers, on average ten people visited per month.

Not all the community participated in ecotourism management in Margasari. Only the community who join the group in Margasari participated in ecotourism. Ecotourism was managed by the village groups; Nelayan Group, Margajaya, PLH, WCB and Pengolah Terasi. WCB and Pengolah Terasi Groups produced some products as souvenir from mangrove. Margajaya group and Nelayan Group provided services as tour guide and transportation by boat around the mangrove forest. PLH Group provided homestays for the visitors, who were most commonly researchers. There were ten members of Nelayan Group who were actively involved in ecotourism, while in PLH Group, only the leader was active. The limited community who joined, in line with Soedigdo and Prino (2013) stated that the community had not joined maximally in providing tourism services. Although, the active participation in ecotourism management had important because the natural knowledge and culture have high value as the ecotourism interest (Hijriati and Mardiana 2014). 
The ecotourism development in Margasari is not currently running well because many facilities have been damaged. The conditions of these facilities have affected visitor interest. As Suchaina (2014) said, if ecotourism place had facilities and infrastructure that are below standard, it could decrease the interest to visit the tourist sites. The facilities which have been damaged are the bird watching tower and mangrove track. The access to the bird watching tower has been closed by the shrimp pond fence and the tower is lower than the mangrove stands. The low maintenance also caused damage to facilities. As stated by Johan (2016) ecotourism in Indonesia has not been developed optimally.

\section{Community perception of ecotourism development}

The community perception of the ecotourism development is divided into several aspects including community knowledge of ecotourism, willingness to participate in ecotourism development, economic benefits of ecotourism for the community, damage caused by visitors and the sustainability of the mangrove ecotourism development in Margasari. The community knowledge of ecotourism was measured based on the community's understanding of the difference between ecotourism and regular tourism. Ecotourism focuses on the concept of nature-based elements in travel activities to enhance visitor experiences, as well as an increased desire to minimize adverse impacts of tourism to the environment and it considers the wellbeing of local people and including educational components in travel activities (Bandara and
Vlosky 2016) different from regular tourism (mass tourism) commonly is artificial tourist attraction and it is not empowering local people (Basyuni et al. 2016).

More than $90 \%$ of Margasari community did not understand the concept of ecotourism. People thought that ecotourism was the same as common tourism. Community members who understood the concept of ecotourism were people who participated in ecotourism management and had the knowledge about ecotourism from the extension program and being active in community group activities. These findings are in line with the research of Kurniawan (2015) who found that member of the Rendoli community thought the ecotourism is a usual tourism tour.

After determining the level of community knowledge, five aspects of ecotourism development were measured. These five perception aspects about the ecotourism development are shown in Table 1.

The willingness of Margasari community to participate in the ecotourism development was high. This willingness is based on a belief that ecotourism activities could increase the community income besides their main livelihood. Margasari community would participate in management planning, counseling of ecotourism development, ecotourism guide, providing homestay, selling and produce souvenir for the visitors. Through the high level of community participation, the ecotourism development in Margasari would be sustainable. As stated by Aflaha (2013), the ecotourism development would run well if the society participation are high and continue to be active.

Table 1. Community perception of ecotourism development

\begin{tabular}{|c|c|c|c|}
\hline Behavior & Agree/willing & Less agree/ willing & Not agree/ willing \\
\hline \multicolumn{4}{|l|}{ Willingness to participate in ecotourism development } \\
\hline Planning activities & 89 & 2 & 8 \\
\hline Tour guide activities & 65 & 12 & 23 \\
\hline Souvenir activities & 97 & 2 & 1 \\
\hline Providing homestay & 70 & 1 & 17 \\
\hline Counselling about ecotourism & 97 & 2 & 1 \\
\hline \multicolumn{4}{|l|}{ Community perception of ecotourism group } \\
\hline Group formation & 98 & 2 & 0 \\
\hline The willingness to join group & 88 & 6 & 5 \\
\hline \multicolumn{4}{|l|}{ Government intervention in Margasari ecotourism } \\
\hline Partial intervene & 98 & 0 & 2 \\
\hline Full intervene & 70 & 10 & 20 \\
\hline \multicolumn{4}{|l|}{ Ecotourism impact on economic benefits } \\
\hline Increase economic benefit for community in Margasari & 11 & 11 & 78 \\
\hline Economic benefit only for some participants & 57 & 6 & 3 \\
\hline \multicolumn{4}{|l|}{ Visitors effect the environment damage } \\
\hline Garbage in forest area & 10 & 1 & 89 \\
\hline Garbage in village & 3 & 86 & 11 \\
\hline Damaging the mangrove trees & 3 & 1 & 96 \\
\hline Damaging the ecotourism facilities & 1 & 3 & 86 \\
\hline Willingness to develop sustainable mangrove ecotourism & 99 & 0 & 1 \\
\hline
\end{tabular}


An ecotourism group is a group that cared about ecotourism and were willing to participate in the ecotourism activities. At this time Margasari has some groups which manage ecotourism, but the management was disorganized. They work individually without organizing by the group. They used the group name to participate in ecotourism because the groups have network to visitor. Outside parties (government, NGOs, universities) that would visit the mangrove area would contact the groups. This limits the participation of other people who were not members of the group. For this reason, it is necessary to develop a new group for tourism purposes to act as $\mathrm{s}$ coordinating institution for all community members who are willing to participate in developing mangrove-based ecotourism. The majority of the Margasari community (88\%) agreed to develop ecotourism group and showed a willingness to join. The participation of local community in ecotourism activities was very important, because they would provide most of the attractions and also determine the quality of the tourism product (Rizky et al. 2016). Besides, according to Pamungkas (2013), the local community could influence the development pattern and the ecotourism policy with the significant diversity in globally.

Mangrove ecosystem has the potential to improve the community prosperity because it has unique and special characteristics, for that the mangrove ecosystem needs to be developed as alternative ecotourism destination (Agussalim and Hartoni 2014; Saputra and Setiawan 2014). The current ecotourism that has been developed in Margasari has not successfully increased the income of the community. Only $12 \%$ of community members had received additional income from mangrove ecotourism. Whereas, the objective of ecotourism is developed prosperity of community which would provide additional livelihood and it increase family income (Hijriati and Mardiana 2014; Manahampi et al. 2015; Sari 2015; Rizky et al. 2016).

Besides community prosperity, one of the ecotourism development goals is to decrease pressure on the forest as a resource (Flamin and Asnaryati 2013). Base on that mangrove ecotourism development needs to consider the possibility of disturbance from visitor. Currently, the disturbance caused by visitors such as environmental damage in mangrove forest ecosystems, ecotourism facilities or the village neighborhood is low. The ecotourism visitors generally are students and researchers both domestic and international with visitor numbers currently at only 5-10 people per month. This number needs to increase so all community in Margasari could participate in mangrove ecotourism.

The ecotourism activities in Margasari have been conducted since 2000 and are well known by the people. Most of Margasari community members $(88 \%)$ agree with the development of mangrove ecotourism. However, the limitation of facilities, infrastructure and the number of visitors become challenging for sustainable development of mangrove ecotourism. The community needs support and collaboration from government and non-government organizations to develop ecotourism in Margasari. Besides, it needs to increase the community capacity and institution reinforcement to manage the mangrove ecotourism. With increasing economic benefits from mangrove ecotourism management, the community surrounding mangrove forests will participate in the protection and preservation of the mangrove forest ecosystem.

Protection effort in the form of prohibition to enter mangrove areas is effective in keeping mangrove sustainable and it reduces environmental damage. However, the prohibition has been limited utilization effort by the community. Whereas, institutional protection by custom rules should provide greater space for civil society to participate in the efforts to achieve sustainability of function and utilization of forest resources (Hidayat 2017). The low economic benefit of mangrove has caused the community participation in mangrove management to decline. Further development of mangrove-based ecotourism is expected to increase community participation in the management of mangrove forests.

\section{ACKNOWLEDGEMENTS}

We would like to thank to Dr. Hj. Bainah Sari Dewi for the suggestion on the manuscript.

\section{REFERENCES}

Aflaha E. 2013. Manfaat mangrove sebagai pelestarian lingkungan hidup di Desa Olaya Kecamatan Parigi Kabupaten Parigi Motu. Jurnal Geo Tadulako UNTAD 1(2): 1-16.

Agussalim, Hartoni. 2014. Potensi kesesuaian mangrove sebagai daerah ekowisata di Pesisir Muara Sungai Musi Kabupaten Banyuasin. Jurnal Maspari 6(2): 148-158.

Ariftia RI, Qurniati R, Hernawati S. 2014. Nilai ekonomi total hutan mangrove Desa Margasari Kecamatan Labuhan Maringgai Kabupaten Lampung Timur. Jurnal Syilva Lestari 2(3): 19-28.

Bandara WARTW, Vlosky R. 2016. Forest-based tourism in Sri Lanka: market segmentation on traveler pre-trip external information search behavior. International Journal of Agriculture, Forestry and Plantation 2: 153-163

Basyuni M, Bimantara Y, Selamet B, Thoha AS. 2016. Identifikasi potensi dan strategi pengembangan ekowisata mangrove di Desa Lubuk Kertang, Kecamatan Brandan Barat, Kabupaten Langkat Sumatera Utara Abdimas Talenta 1 (1): 31-38.

Cesario EA, Qurniati R, Yuwono SB. 2015. Partisipasi kelompok masyarakat dalam pelestarian hutan mangrove di Desa Margasari Kecamatan Labuhan Maringgai Kabupaten Lampung Timur. Jurnal Sylva Lestari 2(5): 21-30.

Herwanti S. 2015. Kajian pengembangan usaha sirup mangrove Desa Margasari Kecamatan Labuhan Maringgai Kabupaten Lampung Timur. Jurnal Hutan Tropis 4(1): 34-40.

Hidayat S. 2017. The use by local communities of plants from Sesaot Protected Forest, West Nusa Tenggara, Indonesia. Biodiversitas 8(1): 238-247.

Hijriati E, Mardiana R, 2014. Pengaruh ekowisata berbasis masyarakat terhadap perubahan kondisi ekologi, sosial, dan ekonomi di Kampong Batusuhunan, Sukabumi. Jurnal Sosiologi Pedesaan 2(3): 146-159.

Johan. 2016. Analisis kesesuaian dan daya dukung ekowisata bahari Pulau Sebesi Privinsi Lampung. Jurnal Depik 2(5): 4147.

Kurniawan. 2015. Peran stakeholder dalam pengembangan ekowisata Desa Rendoli Bogor Jawa Barat. Jurnal Lingkungan 4(6): 67-78.

Kusmana C. 2015. Integrated sustainable mangrove forest management, Jurnal Pengelolaan Sumberdaya Alam dan Lingkungan 5(1): 1-6. 
Kustanti A, Nugroho B, Norrohmact DR, Okimoto Y. 2014. Evolusi hak kepemilikan ekosistem hutan mangrove di Lampung Mangrove Center. Jurnal Risalah Kebijakan Pertanian dan Lingkungan 1(3): 143-158.

Laila NA. 2014. Gerakan masyarakat dalam pelestarian lingkungan hidup. Jurnal Politik Muda 3(3): 283-302.

Manahampi RM, Rengkung LR, Rori YPI, Timban JFJ. 2015. Peranan ekowisata bagi kesejahteraan Masyarakat Bahoi Kecamatan Likuoang Barat. Jurnal ASE 11(3A): 1-18.

Magdalena. 2013. Peran hukum adat dalam pengelolaan dan perlindungan hutan di Desa Sesoat, Nusa Tenggara Barat dan Desa Setulang Kalimantan Timur. Jurnal Penelitan Sosial dan Ekonomi Kehutanan 10(2): 110-121.

Monografi Desa Margasari. 2012. Format potensi, perkembangan, laporan profil desa dan kelurahan. Provinsi Lampung.

Nugraha B, Banuwa IS, Widagdo S. 2015. Perencanaan lanskap ekowisata hutan mangrove di Pantai Sari Ringgung Desa Sidodadi Kecamatan Padang Cermin Kabupaten Pesawaran. Jurnal Sylva Lestari 2(3): 5366.

Pamungkas G. 2013. Ekowisata belum milik bersama: kapasitas jejaring stakeholder dalam pengelolaan ekowisata (Studi Kasus: Taman Nasional Gunung Gede Pangrango). Jurnal Perencanaan Wilyah Dan Kota 24(1): 59-54.

Qurniati R, Febryano IG, Zulfiani D. 2017a. How trust influence socia capital to support collective action in agroforestry development? Biodiversitas 18(3): 1201-1206.

Qurniati R, Hidayat W, Kaskoyo H, Firdasari, Inoue M. 2017b. Social capital in mangrove management: A case study in Lampung Province, Indonesia. Journal of Forest and Environmental Science 33(1): 8-21.
Rizky M, Yunasfi, Lubis MRK. 2016. Kajian potensi ekowisata mangrove di Desa Sialang Buah Kecamatan Teluk Mengkudu Kabupaten Serdang Bedagai. Jurnal Aquacoastmarine 11(1): 68-82.

Rochana E. 2011. Ekowisata mangrove Pesisir Lampung Timur. Lembaga Penelitian. Unila. Bandar Lampung.

Rusdianti K. 2012. Konservasi lahan hutan mangrove serta upaya penduduk lokal dalam merehabilitasi ekosistem mangrove. Jurnal Sosiologi Pedesaan 6(3): 1-17.

Saputra ES, Setiawan A. 2014. Potensi ekowisata hutan mangrove di Desa Merak Belantung Kecamatan Kalianda Kabupaten Lampung Selatan. Jurnal Sylva Lestari 2(2): 49-60.

Sari RI. 2015. Partisipasi masyarakat dalam pengembangan seloringit ecotourism di Dusun Mendiro Desa Panglungan Kecamatan Wonosalam. Jurnal Swara Bhumi 2(3): 42-50.

Sabana C. 2014. Kajian pengembangan produk makanan olahan mangrove. Jurnal Ekonomidan Bisnis 1(14): 40-46.

Soedigdo D, Prino Y. 2013. Peran ekowisata dalam konsep pengembangan pariwisata berbasis masyarakat pada Taman Wisata Alam (TWA) Bukit Tangkling Kalimantan Tengah. Jurnal Prespektif Arsitektur 8(2): 1-8.

Suchaina. 2014. Pengaruh kualitas fasilitas sarana dan prasarana terhadap peningkatan jumlah pengunjung wisata danau ranu granti. Jurnal Psikologi 2(2): 89-109.

Undang-Undang Republik Indonesia Nomor 5 Tahun 1990 tentang Konservasi Sumber Daya Alam Hayati dan Ekosistemnya. Pemerintah Republik Indonesia. Jakarta. 